\title{
Nutrient control of cyanobacterial blooms in the Baltic Sea
}

\author{
Lucas J. Stal*, Marc Staal, Marlies Villbrandt** \\ Netherlands Institute of Ecology, Centre for Estuarine and Coastal Ecology, PO Box 140, 4400 AC Yerseke, The Netherlands
}

\begin{abstract}
Cyanobacterial blooms in the Baltic Sea were investigated with respect to growth limitation and nitrogen fixation. The community was composed predominantly of Synechococcus spp., and large, heterocystous, nitrogen-fixing cyanobacteria (Aphanizomenon spp. and Nodularia spp.), that usually formed buoyant macroscopic aggregates. Although conspicuous, these aggregates often represented less than 20 to $30 \%$ of the total chlorophyll a. Nitrogenase activity was not limited by molybdate availability, but, instead, by high concentrations of sulfate. This may explain inhibition of nitrogenase activity at high salinities. Inhibition of nitrogenase activity at high salinity did not occur when sulfate concentration was kept low. Nitrogen fixation and growth of the diazotrophic cyanobacteria were limited by iron. Synechococcus spp. was primarily nitrogen limited but iron appeared to be the secondary limiting substrate, particularly when these organisms depended on nitrate as the source of nitrogen. Nutrient limitation of the picoplanktonic community was particularly apparent when a wind-induced mixing event occurred. These organisms responded by a subsequent doubling of their biomass within $24 \mathrm{~h}$. Mixing of the water column apparently transported nutrients from greater depth into the euphotic zone, causing a temporary relieve of nitrogen limitation.
\end{abstract}

KEY WORDS: Baltic Sea Cyanobacteria - Bloom Picoplankton · Nutrients - Iron · Nitrogen · Nitrogen fixation $\cdot$ Molybdate $\cdot$ Sulfate

\section{INTRODUCTION}

The Baltic Sea is one of the largest bodies of brackish water in the world. The salinity of the surface waters varies from 1 psu in the northern parts of the Gulf of Bothnia to 7 psu in the central Baltic Proper and further increasing towards the Kattegat, which connects the Baltic Sea with the North Sea (Kullenberg 1981). Due to its higher density, North Sea water entering the Baltic Sea maintains a stable pycnocline at 60 to $80 \mathrm{~m}$ depth, below which the salinity is $>10$ psu. In summer, the surface layers may heat up and form a thermocline at a depth of 15 to $20 \mathrm{~m}$.

The Baltic Sea is characterized by dense summer blooms of cyanobacteria. Such blooms were reported already in the last century and may therefore repre-

\footnotetext{
•E-mail: stal@cemo.nioo.knaw.nl

- Present address: Department of Marine Microbiology, University of Bremen, Leobener Strasse, D-28359 Bremen, Germany
}

sent a natural phenomenon (Leppänen et al. 1988). However, during this century the Baltic Sea has received an increasing input of nutrients (Larsson et al. 1985). Satellite images have shown that the area exhibiting blooms of cyanobacteria has steadily increased (Kahru et al. 1994). This may be blamed on the increased input of nutrients; however, Granéli et al. (1990) argued that the level of eutrophication is not necessarily responsible for the increase in cyanobacterial bloom events.

It is assumed that a low N:P ratio in the water promotes the growth of cyanobacteria in the Baltic Sea (Niemi 1979, Granéli et al. 1990). Low N:P ratios in the surface water occur generally in summer after the decline of the spring bloom of diatoms. Because of the stratification of the Baltic Sea and the sedimentation of organic matter, waters below the thermocline are oxygen depleted. There, denitrification removes inorganic nitrogen from the system while the anoxic conditions promote the flux of phosphate from the bottom sediments (Fonselius 1976). Consequently, this results in a 
low N:P ratio also below the thermocline. With ample phosphate supply, growth of diazotrophic cyanobacteria is promoted (Lindahl et al. 1980, Stockner \& Shortreed 1988). The transition from phosphorus to nitrogen limitation is both seasonal and geographical. For instance, in the Gulf of Bothnia the N:P ratio is high and cyanobacterial blooms do not develop (Niemi 1979, Granéli et al. 1990).

Dinitrogen-fixing organisms grow independent of sources of combined nitrogen such as nitrate, ammonium or amino acids by fixing the ubiquitous $\mathrm{N}_{2}$. The capability of dinitrogen fixation is restricted to specialized prokaryotes. In the Baltic Sea, the diazotrophic cyanobacteria are filamentous, heterocystous species: Aphanizomenon flos-aquae, Nodularia spumigena, Anabaena lemmermannii and Anabaena baltica (Niemi 1979). All the organisms possess gas vesicles, which provide them with buoyancy. In particular, Aphanizomenon spp. and Nodularia spp. are known to form large aggregates, which float rapidly to the surface where they accumulate to very high densities (Walsby et al. 1995).

Heterocysts are special differentiated cells in which the oxygen-sensitive enzyme nitrogenase is protected (Fay 1992, Gallon 1992). These cells are devoid of the oxygen-evolving photosystem II, instead possessing a special envelope that functions as a diffusion barrier for external oxygen (Walsby 1985). Although non-heterocystous diazotrophic cyanobacteria are known (Fay 1992, Gallon 1992), there is no evidence that picoplanktonic cyanobacteria Synechococcus spp., which forms the other, quantitatively important component among Baltic Sea cyanobacteria (Detmer et al. 1993), are capable of nitrogen fixation. It seems that heterocystous cyanobacteria are best adapted to diazotrophic growth and would out-compete non-heterocystous species in this particular N-limited system (Stal 1995). However, because the size of Synechococcus spp. in the Baltic Sea is predominantly smaller than $1 \mu \mathrm{m}$ (Albertano et al. 1997), they have a large surface-volume ratio that makes nutrient uptake efficient at low nutrient concentrations (Stolte et al. 1994, Stolte \& Riegman 1995).

The summer community of phytoplankton is severely nutrient limited (Kivi et al. 1993) but there is uncertainty about which nutrients limit growth. Since the diazotrophic cyanobacteria hardly are nitrogen limited, Leppänen et al. (1988), referring to results of Lindahl, have suggested that the system instead might be phosphorus limited. However, the growth-limiting factor may be not the same for the diazotrophic organisms and the cyanobacterial community as a whole.

In general, marine primary production is considered to be nitrogen limited, although locally phosphate limitation occurs. Hence, it might be expected that nitrogen fixation would cover the nitrogen demand but this seems only partly the case. Nitrogen fixation may contribute only $10 \%$ of the nitrogen requirement for primary production in the Baltic Sea (Leppänen et al. 1988). The crucial question is why this percent is not higher. A hypothesis that has been discussed recently supposes that limited molybdate availability in the marine environment might impair synthesis of nitrogenase (Paulsen et al. 1991, Cole et al. 1993). Molybdenum is a co-factor of nitrogenase. Its oxidized form is assumed to compete with sulfate. Recently, it has been hypothesized that iron limits nitrogen fixation in the pelagic north Atlantic Ocean (Michaels et al. 1996).

The objective of this investigation was to determine which macro- and micronutrients limit growth and nitrogen fixation of the cyanobacterial community.

\section{MATERIALS AND METHODS}

Size fractionation. Size fractions were obtained from samples obtained with a rosette sampler (General Oceanics) with CTD at $0,3,6,9,12,15,18,21,24$ and $27 \mathrm{~m}$ depth. The contents of the $12 \mathrm{l}$ bottle was emptied into a bucket in order to prevent errors caused by buoyant colonies floating up. Samples of $1 \mathrm{l}$ each were filtered through nylon plankton nets of $100,50,25,10$, 5 or $1 \mu \mathrm{m}$ mesh. Another $0.5 \mathrm{l}$ was filtered through Whatman GF-C glass fiber filter $(2.5 \mathrm{~cm})$. The filtrate was subsequently filtered through a $0.2 \mu \mathrm{m}$ membrane filter (Millipore) which did not yield any detectable

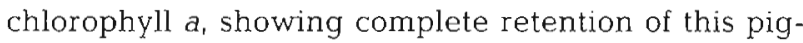
ment by the GF-C filter. For the measurement of the depth distribution of phytoplankton (10 consecutive days), samples were filtered through $20 \mu \mathrm{m}$ mesh plankton net (1 l) and glass fiber filter (0.5 l). It was checked by autofluorescence microscopy that the filtrate of the $20 \mu \mathrm{m}$ mesh plankton net contained essentially only picoplankton. Hence, our procedure separated satisfactorily the large, aggregate-forming cyanobacteria from what essentially appeared to be the fraction of picoplankton.

Determination of chlorophyll a. Chlorophyll a (chl a) was determined by extraction of the filters (see: size fractionation) with $96 \%$ ethanol, overnight in the dark and at room temperature, ensuring complete extraction. The extracts were subsequently kept in the dark at $-20^{\circ} \mathrm{C}$ until measured spectrophotometrically ( 1 to $2 \mathrm{wk}$ ), at $665 \mathrm{~nm}$. The absorption coefficient was $72.3 \mathrm{ml} \mathrm{mg}^{-1} \mathrm{~cm}^{-1}$, determined by using pure chl a (Stal et al. 1984). Tests were run to ensure that storage of extracts at $-20^{\circ} \mathrm{C}$ in the dark did not alter the result of the chl a determination. The standard error of chlorophyll determination was smaller than $10 \%$ 
Picoplankton cell counts and counts of trichomes. Picoplankton cell counts were obtained using a Becton-Dickinson FACSort flow cytometer equipped for fluorescence detection of both chl a and phycoerythrin. The counts were carried out and made available by Dr F. Jochem (Institute of Marine Research of the University of Kiel, Germany). Trichomes were counted using a light microscope and counting chamber $(100 \mu \mathrm{l})$. In total, $1 \mathrm{ml}$ of sample was counted.

Bioassays. Bioassays were carried out with phytoplankton collected from the upper $10 \mathrm{~m}$ of the water column using a $20 \mu \mathrm{m}$ plankton net. This material was resuspended in unfiltered seawater to obtain a chl a concentration in the $>20 \mu \mathrm{m}$ fraction of approximately $10 \mathrm{mg} \mathrm{m}^{-3}$. This is about 10 times the natural concentration. The number of picoplankton cells was about $1.5 \times 10^{4} \mathrm{ml}^{-1}$, identical to the natural density. This is expected because a $20 \mu \mathrm{m}$ filter was used which should not catch the picocyanobacteria. One liter of the phytoplankton suspension was transferred to $1.5 \mathrm{l}$ household food-storage containers made of transparent Plexiglas. The following additions were made: control: no additions; $\mathrm{NH}_{4} \mathrm{Cl}: 1 \mathrm{mM}$ final concentration; $\mathrm{NaNO}_{3}: 1 \mathrm{mM}$ final concentration; $\mathrm{K}_{2} \mathrm{HPO}_{4}: 0.1 \mathrm{mM}$ final concentration; $\mathrm{FeCl}_{3}: 0.1 \mathrm{mM}$ final concentration. All incubations were done in triplicate. A total of 15 containers were put into a large, flat and open tray which was placed in running seawater in order to keep the ambient temperature. The containers were gently aerated using an aquarium pump and a sinter glass block that produced finely dispersed bubbles. The containers were incubated under natural light but were covered with neutral density filter (Lee filter, 2 stops), which attenuated light to $25 \%$, approximating the average irradiance in the upper $10 \mathrm{~m}$ of the water column (average attenuation coefficient $0.353 \mathrm{~m}^{-1}$; Walsby et al. 1997). Light was measured using a LI190SA quantum sensor connected to a LI-1000 data logger (LI-COR, Lincoln, Nebraska, USA). The organisms were incubated for $48 \mathrm{~h}$, after which picocyanobacteria were counted, chl a determined in the $>20 \mu \mathrm{m}$ fraction, the number of trichomes counted, and nitrogenase activity assayed.

In another experiment, in August 1993, samples of a surface bloom of Nodularia spumigena were collected using $100 \mu \mathrm{m}$ plankton net. These samples were suspended in filtered seawater $(0.2 \mu \mathrm{m}$ membrane filters, Millipore). To one of the series, molybdate $(1.7 \mu \mathrm{mol}$ $\mathrm{I}^{-1}$, final concentration) was added, another set of samples was suspended in artificial sulfate-free seawater based on the recipe of ASN 3 (Rippka et al. 1979). In this medium all sulfate was replaced by chloride. A control was included in which the sample was suspended in a medium containing the regular sulfate concentration. Salinity was adjusted to $7 \mathrm{psu}$, corre- sponding to the ambient salinity. These phytoplankton suspensions, which represented approximately $10 \mathrm{mg}$ chl a $\mathrm{m}^{-3}$, were incubated under ambient conditions for $48 \mathrm{~h}$.

In August 1995, a surface bloom of Nodularia spumigena was sampled, using $100 \mu \mathrm{m}$ plankton net. In order to investigate the effects of salinity and sulfateand molybdate concentration on nitrogenase activity, these samples were also re-suspended in artificial seawater based on the recipe of ASN 3, adjusted to $28 \mathrm{psu}$ (North Sea salinity) or 7 psu (local salinity). The full seawater salinity medium contained $28 \mathrm{mM}$ sulfate, and the low-salinity medium $7 \mathrm{mM}$. Effect of sulfate on nitrogenase was measured in low-salinity medium in which the sulfate concentration was either lowered to $1 \mathrm{mM}$ or raised to $28 \mathrm{mM}$. At full-seawater salinity, the effect was studied by lowering the sulfate concentration to $1 \mathrm{mM}$. The molybdate concentration in the artificial seawater was $1.7 \mu \mathrm{M}$. In order to investigate the effect of increased molybdenum availability on nitrogenase activity this concentration was doubled. The suspensions of $N$. spumigena were incubated in the laboratory at $20^{\circ} \mathrm{C}$ and $100 \mu \mathrm{mol}$ photons $\mathrm{m}^{-2} \mathrm{~s}^{-1}$ incident irradiance (PAR), provided continuously by a bank of cool-white fluorescent tubes for $48 \mathrm{~h}$, after which nitrogenase activity was determined.

Assay of nitrogenase activity. Nitrogenase activity was assayed using the acetylene reduction technique using acetylene as internal standard (Stal 1988). Two ml of phytoplankton (usually containing 1 to $2 \mu \mathrm{g}$ of chl a) were transferred to a $10 \mathrm{ml}$ crimp-top glass vial (Chrompack, The Netherlands) and sealed with an aluminum cap with a Teflon-coated rubber septum. Subsequently, $2 \mathrm{ml}$ of acetylene were added and the vials incubated for $2 \mathrm{~h}(12: 30$ to $14: 30 \mathrm{~h})$ under natural light in a tray with running seawater. At the end of the incubation, $5 \mathrm{ml}$ of the headspace were transferred to a $5 \mathrm{ml}$ pre-evacuated crimp-top vial and stored. Upon return in the laboratory, ethylene and acetylene were analyzed gas chromatographically (Stal 1988). Leakage during storage of the gas samples was minimal and by using acetylene as internal standard, corrections for it were made (Stal 1988). After terminating the nitrogenase assay, the chlorophyll content of each vial was determined and acetylene reduction expressed as per chl $a$.

\section{RESULTS}

\section{Distributions of different size classes of phytoplankton}

Most of the chl a (65\%) was found in the size fraction smaller than $1 \mu \mathrm{m}$ (Fig. 1). Another 14\% were found in 


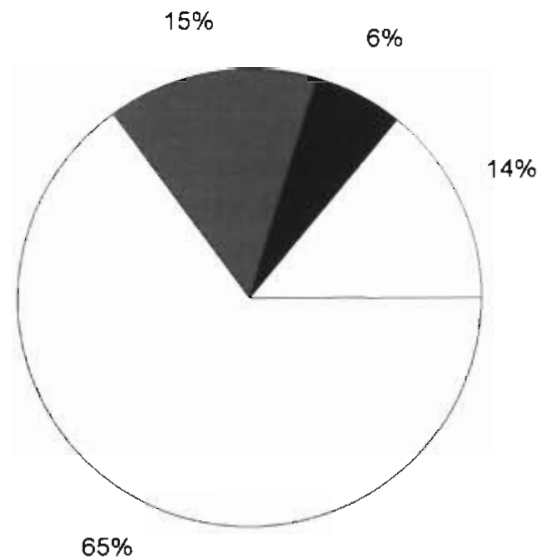

Fig. 1 Size fractionation of chl a of the phytoplankton community of the Baltic Sea. The largest fraction $(65 \%)$ is found in the $<1 \mu \mathrm{m}$ fraction. The larger fractions are 5-10 $\mu \mathrm{m}(15 \%)$, $25-50 \mu \mathrm{m}(6 \%)$ and $>100 \mu \mathrm{m}(14 \%)$. Very little $(<1 \%) \mathrm{chl} a$ was found in the 1-5 $\mu \mathrm{m}$ and $10-25 \mu \mathrm{m}$ fractions. The data represent the average of the $27 \mathrm{~m}$ water column, measured at $3 \mathrm{~m}$ depth intervals

the fraction $>100 \mu \mathrm{m}$ and the rest in intermediate size fractions. The distribution of chl a with depth was essentially the same for several days in July/August 1993 (Fig. 2). The fraction $<20 \mu \mathrm{m}$ thus represents $78 \%$ of the total depth-integrated biomass. Both fractions exhibit highest chl a concentrations in the surface layers.

During a series of 10 successive days (Fig. 3), a big mixing event occurred as a result of a storm on Day 5. Due to this, both fractions were mixed deep into the water column. The $>20 \mu \mathrm{m}$ fraction returned slowly to its original depth distribution (Fig. 3A) but the small-sized fraction increased greatly at virtually all depths (Fig. 3B). The average chl a concentration in the upper $18 \mathrm{~m}$ of the water column shows a

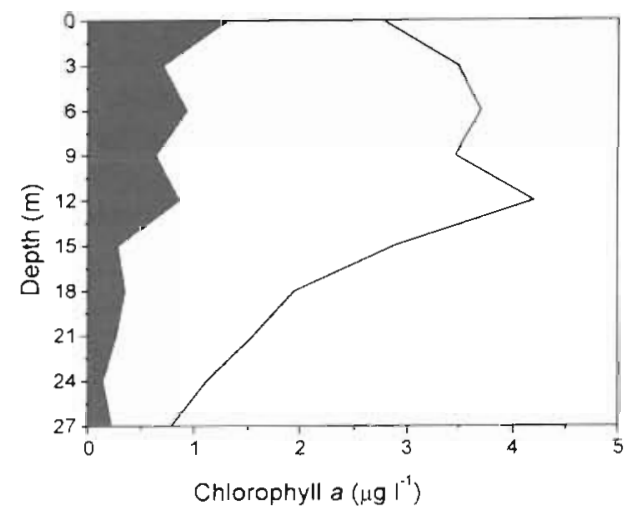

Fig. 2. Depth distribution of chl $a$ in the $>20 \mu \mathrm{m}$ fraction (dark gray) and total chl a (light gray) in the Baltic Sea on August 4 , 09:00 h. The difference between the two represents picoplankton
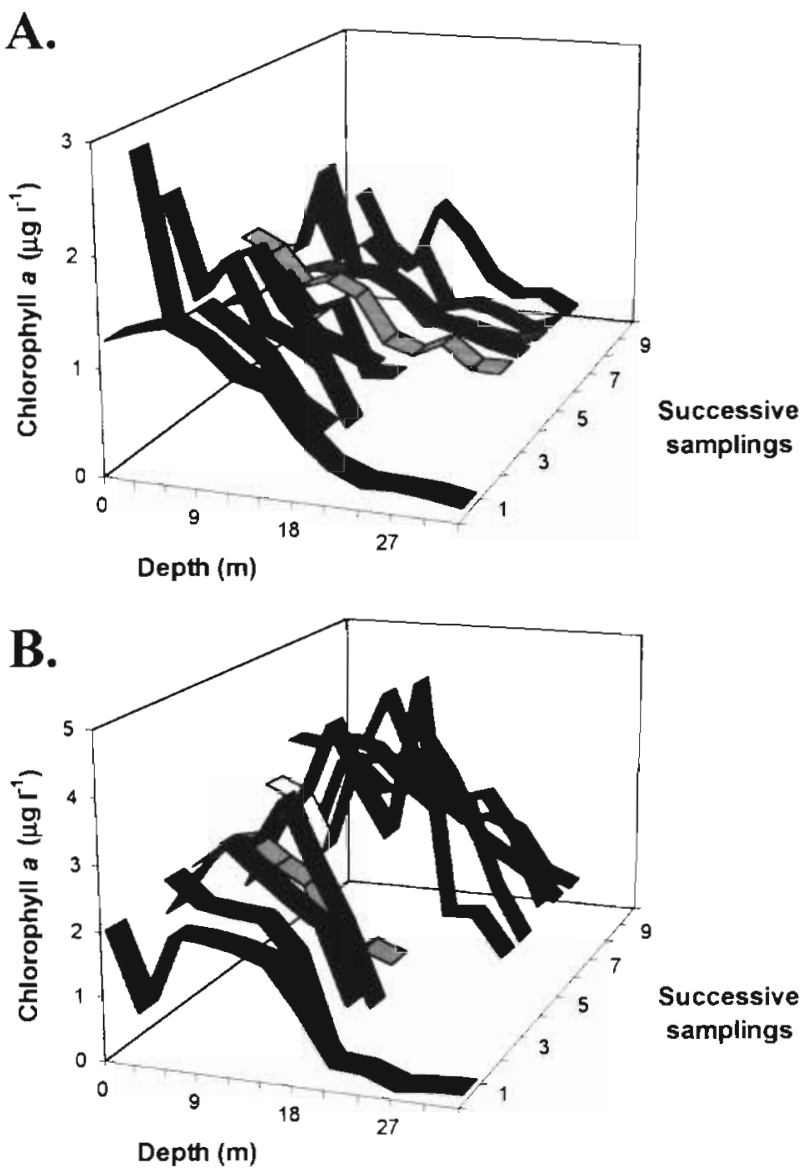

Fig. 3. Depth distributions of chl a (A) in the $>20 \mu \mathrm{m}$ fraction and $(B)$ in the picoplanktonic fraction during 10 successive days

loss of biomass because the storm induced mixing. Whereas the larger fraction did not recover in the following days, a doubling of biomass occurred in the $<20 \mu \mathrm{m}$ fraction during the first $24 \mathrm{~h}$ after the storm (Fig. 4).

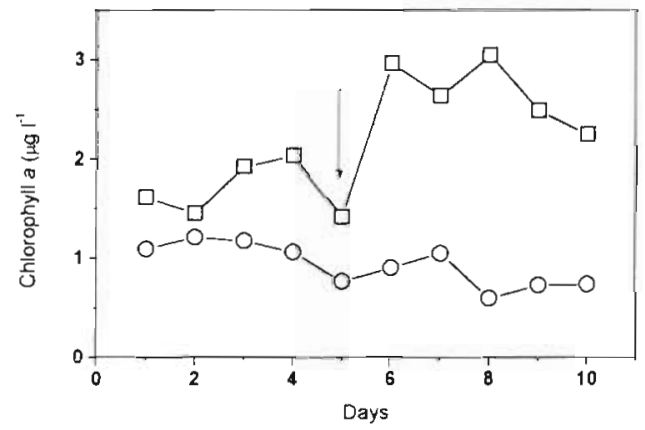

Fig. 4. Average chl a concentrations in the upper $18 \mathrm{~m}$ of the water column for the picoplankton fraction ( $\square$ ) and the $>20 \mu \mathrm{m}$ fraction (O) over 10 successive days. The arrow indicates the storm-induced mixing event 
Table 1. Specific nitrogenase activity in a bloom of Nodularia spumigena incubated under ambient conditions $(1000$ to $1200 \mu \mathrm{mol}$ photons $\mathrm{mm}^{-2} \mathrm{~s}^{-1} ; 20^{\circ} \mathrm{C}$ )

\begin{tabular}{|lc|}
\hline Conditions & $\begin{array}{c}\text { Nitrogenase activity } \\
\left(\mu \mathrm{mol} \mathrm{h}^{-1} \mathrm{mg}^{i} \mathrm{chl} \mathrm{a}\right)\end{array}$ \\
\hline Light (ambient) & $39.7 \pm 9.2$ \\
Light + DCMU $\left(10^{-5} \mathrm{M}\right)$ & $28.4 \pm 10.9$ \\
Dark & $16.2 \pm 0.2$ \\
\hline
\end{tabular}

\section{Nitrogen fixation}

The nitrogenase activity was only slightly sensitive to DCMU (3-(3,4-dichlorophenyl)-1,1-dimethylurea), an inhibitor of photosystem II (Table 1). When incubated in the dark, considerable nitrogenase activity remained but much less than in the light. The light dependence of nitrogenase activity is also evident from the light versus acetylene reduction curve (Fig. 5). The maximum rate of acetylene reduction is reached at about $600 \mu \mathrm{mol}$ photons $\mathrm{m}^{-2} \mathrm{~s}^{-1}$, while above $1200 \mu \mathrm{mol}$ photons $\mathrm{m}^{-2} \mathrm{~s}^{-1}$ a slight inhibition is evident.

\section{Effect of nutrient additions on growth and nitrogenase activity}

From the measurements of chl a and number of trichomes it is clear that only the addition of iron showed a stimulatory effect on growth of Nodularia spumigena (Table 2). Iron also stimulated acetylene reduction. Interestingly, the addition of nitrate or ammonium did not have much effect on nitrogenase activity. Phosphate addition stimulated acetylene reduction to the same extent as iron, but it did not stimulate growth.

In contrast to Nodularia spumigena, the picoplanktonic Synechococcus spp. responded to the addition of ammonium, which resulted in an almost 10-fold increase of cell number (Table 3). Iron also stimulated growth but to a smaller extent. Nitrate did, however,

Table 2. Effect of nutrient additions on biomass, number and nitrogenase activity of field populations of Nodularia spumigena after 48 h of incubation under ambient conditions of light and temperature

\begin{tabular}{|lrcc|}
\hline Incubation & $\begin{array}{c}\mathrm{Chl} a \\
\left(\mu \mathrm{g} \mathrm{m} l^{-1}\right)\end{array}$ & $\begin{array}{c}\text { Trichomes } \\
\left(\mathrm{ml}^{-1}\right)\end{array}$ & $\begin{array}{c}\text { Nitrogenase activity } \\
\left(\mathrm{nmol} \mathrm{C}_{2} \mathrm{H}_{4} \mathrm{mg}^{-1} \mathrm{~h}^{-1}\right)\end{array}$ \\
\hline Control & $12.0 \pm 1.1$ & $246 \pm 35$ & $100 \pm 28$ \\
$\mathrm{NH}_{4} \mathrm{Cl}(1 \mathrm{mM})$ & $9.6 \pm 1.5$ & $268 \pm 37$ & $120 \pm 31$ \\
$\mathrm{NaNO}_{3}(1 \mathrm{mM})$ & $12.4 \pm 0.9$ & $214 \pm 24$ & $79 \pm 3$ \\
$\mathrm{~K}_{2} \mathrm{HPO}_{4}(0.1 \mathrm{mM})$ & $11.2 \pm 1.5$ & $196 \pm 10$ & $220 \pm 0.3$ \\
$\mathrm{FeCl}_{3}(0.1 \mathrm{mM})$ & $15.2 \pm 0.8$ & $344 \pm 32$ & $213 \pm 27$ \\
\hline
\end{tabular}

Table 3. Effect of nutrient additions on Synechococcus spp. cell counts after 48 h of incubation at ambient conditions of light and temperature. Cells were counted by flow cytometry

\begin{tabular}{|lc|}
\hline Incubation & $\begin{array}{c}\text { Cell number }\left(\mathrm{ml}^{-1}\right) \\
(\times 1000)\end{array}$ \\
\hline Control & $17.3 \pm 8.9$ \\
$\mathrm{NH}_{4} \mathrm{Cl}(1 \mathrm{mM})$ & $161.3 \pm 30.3$ \\
$\mathrm{NaNO}_{3}(1 \mathrm{mM})$ & $17.1 \pm 2.3$ \\
$\mathrm{~K}_{2} \mathrm{HPO}_{4}(0.1 \mathrm{mM})$ & $26.7 \pm 7.0$ \\
$\mathrm{FeCl}_{3}(0.1 \mathrm{mM})$ & $67.5 \pm 27.8$ \\
\hline
\end{tabular}

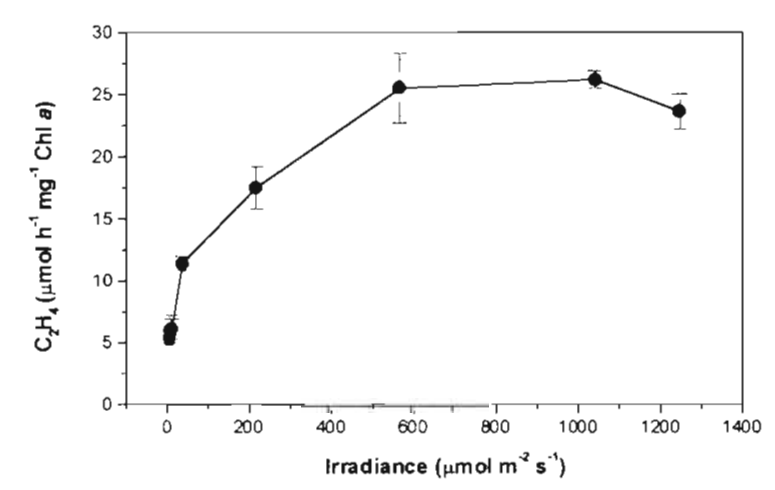

Fig. 5. Nitrogenase activity versus light in a natural population of Nodularia spumigena in the Baltic Sea

not stimulate growth. As for $N$. spumigena, growth of Synechococcus spp. was not stimulated by the addition of phosphate.

\section{Effect of molybdate, salinity and sulfate on nitrogenase activity}

Because it is assumed that cells can take up molybdate and sulfate by using the same transporter, we hypothesized that molybdate uptake should be facilitated by either increasing the molybdate concentration or by lowering the sulfate concentration. Our results show that increasing the molybdate concentration did not affect nitrogenase activity during the course of 48 h (Fig. 6). Unexpectedly, lowering of the sulfate concentration resulted in a strong stimulation of nitrogenase activity. We therefore collected samples of Nodularia spumigena on the next cruise and incubated them in artificial seawater in the laboratory. At 28 psu salinity, nitrogenase activity was inhibited by $>50 \%$ (Fig. 7), whereas increasing the sulfate concentration at 7 psu salinity from 7 to $28 \mathrm{mM}$ neither inhibited nor stimulated the activity significantly (Fig. 7 , 'high $\mathrm{SO}_{4}{ }^{\prime}$ ). However, lowering the sulfate concen- 


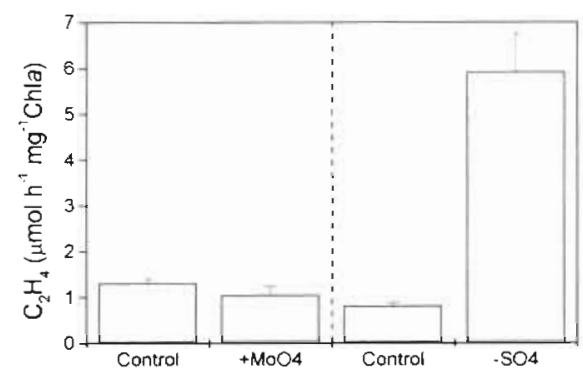

Fig. 6. Effects of molybdate addition or elimination of sulfate on nitrogenase activity in a natural sample of diazotrophic cyanobacteria (mainly Nodularia spumigena) in the Baltic Sea

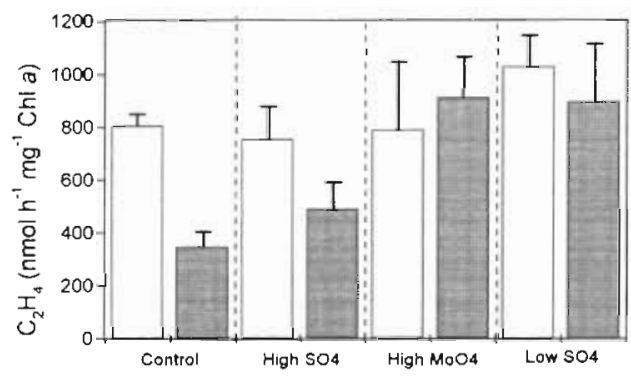

Fig. 7. Nitrogenase activity at full salinity (28 psu, dark gray bars) and 7 psu (light gray bars), combined with high and low sulfate and molybdate concentrations in natural samples of diazotrophic cyanobacteria. High sulfate: sulfate concentration was increased to $28 \mathrm{mM}$. High molybdate: the concentration was increased to $3.4 \mu \mathrm{M}$. Low sulfate: sulfate concentration was decreased to $1 \mathrm{mM}$. Values represent the mean of 3 independent experiments

tration to $1 \mathrm{mM}$ yielded significant stimulation both at 7 and 28 psu salinity, particularly the latter (Fig. 7, 'low $\mathrm{SO}_{4}{ }^{\prime}$ ). In fact, with only $1 \mathrm{mM}$ sulfate present, the nitrogenase activity was the same at 2 salinities. In the full seawater salinity medium a doubling of the concentration of molybdate gave stimulation of nitrogenase activity similar to that at low sulfate concentration (Fig. 7, 'high $\mathrm{MoO}_{4}{ }^{\prime}$ ).

\section{DISCUSSION}

The size fractionation of chl a indicated that $65 \%$ was found in the fraction smaller than $1 \mu \mathrm{m}$. This confirmed the observations of Albertano et al. (1997) who demonstrated that $73.6 \%$ of the picoplankton of the Baltic Sea was considerably smaller than $1 \mu \mathrm{m}$, while the remaining fraction was slightly larger Very little chl a was found in the fraction 10 to $25 \mu \mathrm{m}$. Therefore, virtually all chl a that passed the $25 \mu \mathrm{m}$ plankton net can be attributed to picoplankton (by definition $<2 \mu \mathrm{m}), 80 \%$ of the total chl a. Routinely, a $20 \mu \mathrm{m}$ plankton net was used for separating the larger, dia- zotrophic cyanobacteria from the picoplankton. Also in this case $80 \%$ of the depth integrated $(27 \mathrm{~m}) \mathrm{chl}$ a passed the $20 \mu \mathrm{m}$ plankton net (Fig. 2).

The $>20 \mu \mathrm{m}$ fraction consisted of cyanobacteria that possess gas vesicles. These vesicles provide the organisms with buoyancy and the rate with which they float up increases with the square of the diameter of the aggregate. Colonies of Aphanizomenon flos-aquae may float up at velocities of 5 to $35 \mathrm{~m} \mathrm{~d}^{-1}$ (Walsby et al. 1995). However, even when the water column is stable for prolonged periods of time, Walsby et al. (1997) found that only $37 \%$ of the colonies that were present in the top $21 \mathrm{~m}$ of the water column floated at the water surface. The vertical distribution of chl a in the $>20 \mu \mathrm{m}$ fraction confirms earlier data for the distribution of colonies of A. flos-aquae (Walsby et al. 1995, 1997). The depth distribution of chl $a$ in the $<20 \mu \mathrm{m}$ fraction also showed the same pattern with accumulation towards the surface and a subsurface maximum at around $10 \mathrm{~m}$ depth. Because picoplanktonic cyanobacteria do not possess gas vesicles they have a higher density than water; however, due to their small size they sink very slowly. The higher abundance in the top layer of the water column could be explained by growth exceeding losses by sinking. The subsurface maximum may be attributed to phycoerythrin-containing Synechococcus spp., which is known to be lowlight adapted (Wood 1985).

The experiment at the drift station during 10 successive days is unique because of the storm that mixed the water mass at Day 5. The picoplankton responded by doubling the total depth integrated biomass within approximately 24 h after the storm (Fig. 4). Meso-scale physical forcing is an important process transporting nutrients from deeper layers into the euphotic zone (Nômmann \& Kaasik 1992). It is likely that the picoplankton experienced a temporary relief of nutrient limitation. A doubling time of less than $24 \mathrm{~h}$ is not unexpected considering that strains of Synechococcus spp. isolated from the Baltic Sea can grow at rates up to $\pm 0.03 \mathrm{~h}^{-1}$ (Stal \& Staal unpubl.).

The depth-integrated biomass of the $>20 \mu \mathrm{m}$ fraction was hardly affected by this great mixing event and rather decreased. Apparently, the mixing event did not alleviate growth limitation in this fraction, or may have been too slow to effect an increase in biomass during the few days of observation. The $>20 \mu \mathrm{m}$ fraction was deeply mixed during the storm and recovered slowly. There was only a weak tendency of floating up. This seems in contradiction with the observations of Walsby et al. (1997) during the same period. They reported that Aphanizomenon colonies floated to the surface. However, this species represented only $40 \%$ of the total chl $a$ in the $>20 \mu \mathrm{m}$ fraction, while the other $60 \%$ was Nodularia spp. The latter apparently floated up 
much slower, which might have been due to the fact that the storm disrupted the colonies of this species.

The $>20 \mu \mathrm{m}$ fraction consisted predominantly of Nodularia spumigena and Aphanizomenon flos-aquae, both heterocystous and nitrogen-fixing. Their specific rates of nitrogenase activity were high. Nitrogenase was clearly light dependent and was inhibited only to a small extent by the inhibitor of oxygenic photosynthesis, DCMU, typical for heterocystous cyanobacteria (Stal 1995). Nitrogenase activity was saturated at about $600 \mu \mathrm{mol}$ photons $\mathrm{m}^{-2} \mathrm{~s}^{-1}$, but considerable activity was also found in the dark. It therefore seems unlikely that $N$. spumigena and A. flos-aquae were nitrogen limited. Moreover, we found no evidence that the $<20 \mu \mathrm{m}$ fraction was capable of fixing nitrogen, and none of the isolates of Synechococcus spp. possess this capacity (own unpubl. obs.).

The bioassays clearly demonstrated that the diazotrophic cyanobacteria were limited by iron, which stimulated both growth and nitrogenase activity. The addition of iron caused a significant increase in the chl a content, number of trichomes and nitrogenase activity. Phosphate stimulated nitrogenase activity to the same extent as iron but did not stimulate growth. It has been reported by others that nitrogen fixation does not proceed efficiently when phosphate concentrations are low (Lindahl et al. 1980, Stockner \& Shortreed 1988). The addition of phosphate may therefore have lead to higher nitrogen fixation but without stimulating growth because the lack of iron.

Although required in trace amounts, iron is a key element in a variety of essential processes in the cell. It is a co-factor in many enzymes, including nitrogenase and nitrate reductase. It is also a co-factor in cytochromes. Recently, iron has received increased attention as the possible limiting factor also for oceanic primary productivity (Kolber et al. 1994, Wells et al. 1994, Cullen 1995, De Baar et al. 1995), for nitrate reduction (Timmermans et al 1994), and for nitrogen fixation in the marine environment (Michaels et al. 1996, Falkowsky 1997, Paerl 1997). In aerobic environments iron occurs in the ferric $\left(\mathrm{Fe}^{3+}\right)$ state, which is virtually insoluble. Therefore, iron concentrations in the sea are very low. Input of iron is supposed to occur from terrestrial dust depositing in the sea (Michaels et al. 1996). Microorganisms often produce siderophores, compounds with a very high binding affinity for iron. It is not known whether the Baltic Sea cyanobacteria produce siderophores.

Another remarkable bioassay result was that the addition of nitrogenous compounds such as ammonia or nitrate did not or hardly affected nitrogenase activity. Because these compounds are known to inhibit nitrogenase, the continued nitrogenase activity we observed may be related to iron being unavailable.
This argument does, however, not hold for ammonium. It has been observed earlier in natural communities of benthic or planktonic diazotrophic cyanobacteria that ammonium has no effect on nitrogenase activity, unless added at concentrations $>5 \mathrm{mM}$, which is a toxic level (Stal unpubl, obs.). Currently, there is no good explanation for this observation.

We assume that nitrogen was the limiting factor for the picoplanktonic Synechococcus spp, because the addition of ammonium resulted in an almost 10 -fold increase of the cell density during a $48 \mathrm{~h}$ incubation. This would be possible with a doubling time of Synechococcus spp. of about $16 \mathrm{~h}$, which approaches the doubling time achieved in laboratory cultures of strains isolated from the Baltic Sea (Stal \& Staal unpubl. obs.). Synechococcus spp. also receive nitrogen directly from the diazotrophic cyanobacteria and it has been calculated that 10 to $20 \%$ of the nitrogen fixed is transferred (Stal \& Walsby 1998).

The absence of stimulation of growth of Synechococcus spp. by nitrate is not likely to be due to the incapability of Synechococcus spp. of assimilating nitrate because these organisms grew well on nitrate in the laboratory culture. More probably, the unavailability of iron prevented Synechococcus spp. from utilizing nitrate. Iron is an important component of ferredoxin, which serves as electron donor for assimilatory nitrate reduction (Guerrero \& Lara 1987). Timmermans et al. (1994) have shown that iron limitation severely impaired nitrate reduction.

The limited availability of iron for planktonic cyanobacteria in the Baltic Sea has important ecological consequences for the nitrogen cycle. Instead of being assimilated for new production, nitrate becomes available for e.g. denitrification resulting in the removal of bound nitrogen. At the same time iron also hampers nitrogen fixation. This may also explain why nitrogen fixation accounts for only $10 \%$ of the total nitrogen requirement for primary production in the Baltic Sea (Leppänen et al. 1988).

It has been hypothesized that molybdenum availability impairs the synthesis of nitrogenase in the marine environment (Paulsen et al. 1991, Cole et al. 1993). Like iron, it is a co-factor of nitrogenase. It occurs in seawater as molybdate, but in contrast to iron it is very soluble. However, the uptake of molybdate may be hampered because it is thought to compete with sulfate. Our results indicate that an increase of molybdate concentration in Baltic Sea water did not stimulate nitrogenase activity, confirming the observations made by Paulsen et al. (1991). Instead, elimination of sulfate stimulated nitrogenase activity strongly. This observation supports the molybdate hypothesis. It is known that an increase in salinity normally impairs nitrogen fixation seriously (Fernandes et al. 1993), 
Baltic Sea cyanobacteria being no exception. This is generally attributed to the lack of efficient osmoregulation or by the increased energy demand. However, the inhibitory effect of high ( 28 psu) salinity could be completely alleviated by either lowering the sulfate concentration to fresh water level (1 $\mathrm{mM})$ or by increasing the molybdate concentration. We hypothesize that the cell loses ATP and reduction equivalents (ferredoxin) due to assimilatory sulfate reduction. The reduced sulfur cannot be sufficiently rapidly assimilated due to the limitation of growth by iron. Elevation of the molybdate concentration may competitively inhibit sulfate uptake and, more importantly, it interacts with sulfate reduction. Molybdate blocks the formation of adenosine-5'-phosphosulfate, an intermediate in the reduction of sulfate, while hydrolyzing ATP (Oremland \& Capone 1988). This possibility is now being investigated.

Acknowledgements. This work was subsidized by the European Community, Environment and Climate RTD programme, contract number EV5V-CT94-0404 and carried out at the Laboratory for Microbiology, University of Amsterdam. The authors thank the crew of RV 'Alkor', Dr W. Van Dok for her advice and help in some of the experiments and Dr F. Jochem for carrying out the picoplankton cell count using flow cytometry. The comments of 2 anonymous referees are gratefully acknowledged. This is publication 2489 of NIOOCEMO

\section{LITERATURE CITED}

Albertano P, Di Somma D, Capucci E (1997) Cyanobacterial picoplankton from the Central Baltic Sea: cell size classification by image-analyzed fluorescence microscopy. J Plankton Res 19:1405-14:16

Cole JJ, Lane JM, Marino R, Howarth RW (1993) Molybdenum assimilation by cyanobacteria and phytoplankton in freshwater and salt water. Limnol Oceanogr 38:25-35

Cullen JJ (1995) Status of the iron hypothesis after the openocean enrichment experiment. Limnol Oceanogr 40: $1336-1343$

De Baar HJW, De Jong JTM, Bakker DCE, Loscher BM, Veth C, Bathmann U, Smetacek V (1995) Importance of iron for plankton blooms and carbon dioxide drawdown in the southern ocean. Nature 373:412-415

Detmer AE, Giesenhagen HC, Trenkel VM, Venne HAD, Jochem FJ (1993) Phototrophic and heterotrophic picoplankton and nanoplankton in anoxic depths of the central Baltic Sea. Mar Ecol Prog Ser 99:197-203

Falkowski PG (1997) Evolution of the nitrogen cycle and its evolution on the biological sequestration of $\mathrm{CO}_{2}$ in the ocean. Nature 387:272-274

Fay $P$ (1992) Oxygen relations of nitrogen fixation in cyanobacteria. Microbiol Rev 56:340-373

Fernandes TA, lyer V, Apte K (1993) Differential responses of nitrogen-fixing cyanobacteria to salinity and osmotic stresses. Appl Environ Microbiol 59:899-904

Fonselius $\mathrm{S}(1976)$ On the nutrient variability in the Baltic. Ambio 4:17-25

Gallon JR (1992) Reconciling the incompatible: $N_{2}$ fixation and $\mathrm{O}_{2}$. New Phytol 122:571-609
Granéli E, Wallström U, Larsson U, Granéli W. Elmgren R (1990) Nutrient limitation of primary production in the Baltic Sea area. Ambio 19:142-151

Guerrero MG, Lara C (1987) Assimilation of inorganic nitrogen. In: Fay $P$, Van Baalen $C$ (eds) The cyanobacteria. Elsevier Science Publishers, Amsterdam, p 163-186

Kahru M, Horstmann U, Rud O (1994) Satellite detection of increased cyanobacterial blooms in the Baltic Sea: natural fluctuation or ecosystem change? Ambio 23:469-472

Kivi K, Kaitala S, Kuosa H, Kuparinen J, Leskinen E, Lignell $R$, Marcussen B, Tamminen T (1993) Nutrient limitation and grazing control of the Baltic plankton community during annual succession. Limnol Oceanogr 38:893-905

Kolber ZS, Barber RT, Coale KH, Fitzwater SE, Greene RM, Johnson KS, Lindley S, Falkowski PG (1994) Iron limitation of phytoplankton photosynthesis in the equatorial pacific ocean. Nature 371:145-149

Kullenberg G (1981) Physical oceanography. In: Voipio A (ed) The Baltic Sea. Elsevier Science Publishers, Amsterdam, p 135-181

Larsson U, Elmgren R, Wulff $F$ (1985) Eutrophication and the Baltic Sea: causes and consequences. Ambio 14:9-14

Leppänen JM, Niemi $\AA$, Rinne I (1988) Nitrogen fixation of cyanobacteria (blue-green algae) and the nitrogen cycle of the Baltic Sea. Symbiosis 6:181-194

Lindahl G, Wallström K, Brattberg G (1980) Short-term variations in nitrogen fixation in a coastal area of the Northern Baltic. Arch Hydrobiol 89:88-100

Michaels AF, Olson D, Sarmiento JL, Ammerman JW, Fanning $\mathrm{K}$, Jahnke R, Knap AH, Lipschultz F, Prospero JM (1996) Inputs, losses and transformations of nitrogen and phosphorus in the pelagic North Atlantic Ocean. Biogeochemistry 35:181-226

Niemi $\AA$ (1979) Blue-green algal blooms and N:P ratio in the Baltic Sea. Acta Bot Fennica 110:57-61

Nômmann S, Kaasik E (1992) Hydrodynamical control of phytoplankton succession during the vernal light-limited phase in the Baltic Sea. Mar Ecol Prog Ser 84:279-292

Oremland RS, Capone DG (1988) Use of 'specific' inhibitors in biogeochemistry and microbial ecology. Adv Microbial Ecol 10:285-383

Paerl HW (1997) Coastal eutrophication and harmful algal blooms: importance of atmospheric deposition and groundwater as 'new' nitrogen and other nutrient sources. Limnol Oceanogr 42:1154-1165

Paulsen DM, Paerl HW, Bishop PE (1991) Evidence that molybdenum-dependent nitrogen fixation is not limited by high sulfate concentrations in marine environments Limnol Oceanogr 36:1325-1334

Rippka R, Deruelles J, Waterbury JB, Herdman M, Stanier RY (1979) Generic assignments strain histories and properties of pure cultures of cyanobacteria. J Gen Microbiol 111 $1-61$

Stal LJ (1988) Nitrogen fixation in microbial mats. Meth Enzymol. 167:474-484

Stal LJ (1995) Physiological ecology of cyanobacteria in microbial mats and other communities. New Phytol 131:1-32

Stal LJ. Walsby AE (1998) The daily integral of nitrogen fixation by planktonic cyanobacteria in the Baltic Sea. New Phytol 139:665-671

Stal LJ, van Gemerden H, Krumbein WE (1984) The simultaneous assay of chlorophyll and bacteriochlorophyll in natural microbial communities. J Microbiol Meth 2:295-306

Stockner JG. Shortreed KS (1988) Response of Anabaena and Synechococcus to manipulation of nitrogen:phosphorus ratios in a lake fertilization experiment. Limnol Oceanogr $33: 1348-1361$ 
Stolte W, Riegman R (1995) The effect of phytoplankton cell size on transient state nitrate and ammonium uptake kinetics. Microbiol 141:1221-1229

Stolte W, McCollin T, Noordeloos AAM, Riegman R (1994) Effect of nitrogen source on the size distribution within phytoplankton populations. J Exp Mar Biol Ecol 184: $83-97$

Timmermans KR, Stolte $W$, de Baar HJW (1994) Iron-mediated effects on nitrate reductase in marine phytoplankton. Mar Biol 121:389-396

Walsby AE (1985) The permeability of heterocysts to the gases nitrogen and oxygen. Proc R Soc Lond B 226: $345-366$

Editorial responsibility: Frede Thingstad,

Bergen, Norway
Walsby AE, Hayes PK, Boje R (1995) The gas vesicles, buoyancy and vertical distribution of cyanobacteria in the Baltic Sea. Eur J Phycol 30:87-94

Walsby AE, Hayes PK, Boje R, Stal LJ (1997) The selective advantage of buoyancy provided by gas vesicles for planktonic cyanobacteria in the Baltic Sea. New Phytol 136:407-417

Wells ML, Price NM, Bruland KW (1994) Iron limitation and the cyanobacterium Synechococcus in equatorial pacific waters. Limnol Oceanogr 39:1481-1486

Wood AM (1985) Adaptation of photosynthetic apparatus of marine ultraphytoplankton to natural light fields. Nature 316:253-255

Submitted: August 6, 1998; Accepted: January 13, 1999

Proofs received from author(s): July 16, 1999 